\title{
Phytosanitary quality of Brachiaria brizantha 'BRS Piatã' seeds in function of climate conditions
}

\author{
Givanildo Z. da Silva ${ }^{1}$, Cibele C. Martins ${ }^{2}$, Luciana C. do Nascimento ${ }^{3}$, \\ Gabriel G. Barreto ${ }^{3} \&$ Otília R. de Farias ${ }^{3}$ \\ ${ }^{1}$ Universidade Federal de Goiás/Regional de Jataí. Jataí, GO, Brasil. E-mail: givanildozildo@hotmail.com (Corresponding author) - ORCID: 0000-0002-6380-1599 \\ ${ }^{2}$ Universidade Estadual Paulista 'Júlio Mesquita Filho'/Faculdade de Ciências Agrárias e Veterinárias. Jaboticabal, SP, Brasil. E-mail: cibele.chalita@unesp.br - ORCID: 0000-0002- \\ $1720-9252$ \\ ${ }^{3}$ Universidade Federal da Paraiba/Centro de Ciências Agrárias/Departamento de Fitotecnia e Ciências Ambientais. Areia, PB, Brasil. E-mail: luciana.fitopatologia@gmail.com - \\ ORCID: 0000-0001-7774-6837; gabrielginane@hotmail.com - ORCID: 0000-0002-4644-7938; otiliarfarias@gmail.com - ORCID: 0000-0002-0753-0712
}

\begin{abstract}
Infected seeds are one of the main pathogen transmission vehicles, and they are responsible for significant losses in production fields; phytosanitary defense depends on the inoculum and climatic factors. Thus, in this study, it was aimed to identify climatic variables of the regions that propitiate the production of Brachiaria brizantha 'BRS Piatã' seeds infected with phytopathogenic fungi. Temperature and rainfall data were obtained from 10 production fields, and phytosanitary quality of the seeds was evaluated with the filter paper method; the means were compared using the Kruskal-Wallis non-parametric analysis. Principal component analysis was performed to determine the relationship between the climatic variables and seed phytosanitary quality. Sites with maximum temperatures higher than $30^{\circ} \mathrm{C}$, mean values close to $25^{\circ} \mathrm{C}$, and rainfall less than $82 \mathrm{~mm}$ during harvest were favorable to the incidence of Fusarium spp. The incidence of Bipolaris sp. in the seeds of Piatã grass was favored by temperatures around 19 and $20^{\circ} \mathrm{C}$ during the maturation phase. The highest incidence of Exserohilum sp. occurred at the sites in which the temperature during harvest was close to $20^{\circ} \mathrm{C}$ and accumulated rainfall, between 167 and $181 \mathrm{~mm}$.
\end{abstract}

Key words: forage grasses, Piatã grass, temperature, humidity, phytosanitary barrier

\section{Qualidade sanitária de sementes de Brachiaria brizantha 'BRS Piatã' em função de condições climáticas}

RESUMO: A semente infectada é um dos principais veículos de transmissão de patógenos, responsáveis por perdas significativas em campos de produção e, as condições sanitárias destas dependem do inóculo e dos fatores climáticos presentes. Assim, objetivou-se identificar variáveis climáticas das regiões que propiciam a produção de sementes de Brachiaria brizantha, cv. BRS 'Piatã, infectadas com fungos fitopatogênicos. Foram obtidos dados de temperatura e precipitação de 10 campos de produção e a sanidade das sementes foi avaliada pelo método do papel de filtro, com as médias comparadas pela análise não-paramétrica de Kruskal-Wallis. Para determinar a relação entre variáveis climáticas e a sanidade das sementes aplicou-se a análise de componentes principais. Locais com temperaturas máximas superiores a $30^{\circ} \mathrm{C}$, médias próximas a $25^{\circ} \mathrm{C}$ e acúmulo de chuva inferior a $82 \mathrm{~mm}$ na colheita foram favoráveis à incidência de Fusarium spp.. A incidência de Bipolaris sp. em sementes de capim-piatã na fase de maturação é favorecida por temperaturas em torno de 19 e $20^{\circ} \mathrm{C}$. A maior incidência de Exserohilum sp. ocorre em locais cuja temperatura durante a colheita é próxima a $20^{\circ} \mathrm{C}$ e a precipitação pluviométrica acumulada situa-se entre 167 e $181 \mathrm{~mm}$.

Palavras-chave: gramíneas forrageiras, capim-piatã, temperatura, umidade, barreira fitossanitária 


\section{INTRODUCTION}

The presence of pathogens in seeds represents a risk for phytosanitary defense, as these pathogens may serve as a source of inoculum in areas free of contamination (Mallmann et al., 2013; Santos et al., 2014). Currently, there is a demand by the sector forage grass to identify favorable regions and produce high-quality seeds (Martins et al., 2017; Melo et al., 2017). Thus, analysis of the production and technology associated with forage grass seeds has the potential to generate information on the best regions for production.

Commonly, fields used for the production of forage grass seeds occupy traditional pasture areas. However, a region is not the best for seed production only because a plant has adapted well to a certain region and produces a large amount of green mass suitable for animal nutrition and weight gain (Souza, 2001; Araújo et al., 2008).

Environmental factors such as temperature, precipitation, water stress, and relative humidity may favor the spread of diseases in plants and seeds (Amorim et al., 2016). The genera Bipolaris, Curvularia, Fusarium and Phoma have been identified in Brachiaria brizantha seeds from different fields in Mato Grosso (Mallmann et al., 2013). However, the authors did not identify climatic conditions that favored the incidence of these fungi in the seeds. The objective of this study was to identify climatic variables that favor the production of B. brizantha 'BRS Piatã' seeds infected with phytopathogenic fungi.

\section{Material ANd Methods}

The study was performed with $B$. brizantha 'BRS Piatã' seeds harvested from 10 production fields in Brazil (Table 1). These fields showed differences of more than $5^{\circ} \mathrm{C}$ in temperature and more than $100 \mathrm{~mm}$ in precipitation. The existence of climatic differences was confirmed in the seed production fields because the standard deviation of the climatic parameters was greater than 2 .

The data on rainfall and temperature (minimum, mean, and maximum) were obtained from INMET (2018) during the reproductive cycle, from the first flowering until the last seed falls (known as the maturation period), as well as the harvest (from December 2014 to August 2015), depending on the region. Information on the fields during the flowering period (between the first and second flowering), seed falling period, and harvest period was obtained from the cooperative farmers, company technicians, and survey reports of the fields, which are requirements of the Ministry of Agriculture, Livestock and Supply (Brasil, 2008).

To harvest the seeds, the plants were first cut with an enclosed mower, and, then, a harvester swept up the top layer of the soil and seeds; this material was ventilated and sieved to remove the impurities. In the field, $5 \mathrm{~kg}$ samples of crude seeds were packed using paper and sent for analysis to the Seed Analysis Laboratory at the Phytosanitary Department of the Federal University of Paraíba, Center of Agrarian Sciences, Areia Campus, PB.

To determine the incidence of fungi in the seeds, the blotter test was performed using 20 replicates of 10 seeds equidistantly distributed on three sheets of sterile filter paper, previously moistened with sterile distilled water, and incubated in petri dishes $\left(9 \mathrm{~cm}\right.$ in diameter) for seven days at $20^{\circ} \mathrm{C}\left( \pm 2{ }^{\circ} \mathrm{C}\right)$ and $12 \mathrm{~h}$ of light (Brasil, 2009). The seeds were analyzed individually under a stereoscopic microscope, and the fungi were identified using their morphological characteristics (Seifert et al., 2011). The results were expressed as the percentage of seeds contaminated by each fungus (Brasil, 2009).

To interpret the results, the detected fungi were divided into three categories on the basis of incidence: (i) high, greater than $3 \%$; (ii) average, between 0.5 and $2.8 \%$; and (iii) low, less than $0.5 \%$ (Melo et al., 2017).

The experimental design was completely randomized, with 20 replicates of 10 seeds per lot. The statistical procedure was divided into two stages. In the first stage, univariate statistical analysis was performed. The data were tested for normality and homoscedasticity by using the Shapiro-Wilk and Cochran tests, respectively. If the basic hypotheses for ANOVA were not met, the Kruskal-Wallis nonparametric analysis was performed; if the result was significant, the t-test was used to compare the mean values.

In the second stage, multivariate analysis was performed, according to Hongyu et al. (2015). Thirteen climatic and sanitary quality variables were selected from the seeds that showed differences in these variables in the production fields. The data was subjected to multivariate statistical analysis by performing principal component analysis with the

Table 1. Time of maturation $(\mathrm{M})$ and harvesting $(\mathrm{H})$, minimum temperature at maturation $(\mathrm{T}-\mathrm{M})$ and at harvesting $(\mathrm{T}-\mathrm{H})$, mean temperature at maturation $(\mathrm{TmM})$ and at harvesting $(\mathrm{TmH})$, maximum temperature at maturation $(\mathrm{T}+\mathrm{M})$ and at harvesting $(\mathrm{T}+\mathrm{H})$ and accumulated rainfall at maturation (RM) and at harvesting (RH) of the Brachiaria brizantha 'BRS Piatã' seed lots from different production fields 2014/2015

\begin{tabular}{|c|c|c|c|c|c|c|c|c|c|c|}
\hline \multirow{2}{*}{ Production regions } & M & H & T-M & T-H & $\mathrm{TmM}$ & $\mathrm{TmH}$ & $T+M$ & $\mathrm{~T}+\mathrm{H}$ & RM & RH \\
\hline & \multicolumn{2}{|c|}{ Month } & \multicolumn{6}{|c|}{$\left({ }^{\circ} \mathrm{C}\right)$} & \multicolumn{2}{|c|}{$(\mathrm{mm})$} \\
\hline Santo Anastácio - SP & Dec-Apr & May-Jun & 21.5 & 16.9 & 25.7 & 21.0 & 31.4 & 26.4 & 826 & 181 \\
\hline Dracena - SP & Dec-Apr & May-Jun & 21.5 & 16.7 & 25.9 & 21.3 & 32.4 & 27.6 & 928 & 167 \\
\hline Jataí - G0 & Dec-Apr & May-Jul & 20.1 & 15.1 & 25.7 & 22.1 & 31.4 & 29.1 & 1024 & 137 \\
\hline Palmeiras de Goiás - G0 & Jan-Apr & May-Jun & 20.5 & 17.7 & 26.1 & 23.9 & 31.6 & 30.0 & 815 & 71 \\
\hline São Desidério - BA & Dec-Apr & May-Jun & 21.3 & 18.5 & 25.9 & 24.2 & 32.3 & 32.0 & 903 & 15 \\
\hline Correntina - BA & Dec-Apr & May-Jun & 19.1 & 15.2 & 24.9 & 22.2 & 32.1 & 30.3 & 709 & 47 \\
\hline Tupaciguara - MG & Jan-Apr & May-Jul & 20.3 & 17.0 & 24.9 & 21.8 & 29.6 & 26.5 & 762 & 83 \\
\hline Unaí - MG & Dec-Apr & May-Jul & 21.0 & 16.7 & 25.8 & 22.8 & 32.0 & 29.7 & 914 & 41 \\
\hline Costa Rica - MS & Dec-May & Jun-Jul & 19.2 & 15.6 & 24.7 & 22.4 & 30.2 & 29.1 & 1126 & 39 \\
\hline Paraíso das Águas - MS & Dec-May & Jun-Jul & 20.0 & 15.5 & 24.0 & 21.3 & 28.9 & 27.1 & 1011 & 31 \\
\hline
\end{tabular}

Fonte: INMET (2018) 
Software Assistat, version 7.7 (Silva \& Azevedo, 2016), after standardization of the null mean and unit variance.

\section{Results AND Discussion}

Sanitary analysis of $B$. brizantha 'BRS Piatã' seeds was performed, and 37 fungal genera, with a total mean incidence of $0.1-27 \%$, were detected in the seeds. Of these, 21 were considered low incidence because they were found in less than $0.6 \%$ of the seeds. The 21 genera were as follows: Ustilago, Trichoconiella, Torula, Tetraploa, Pestalotia, Pantaspora, Mucor, Monacrosporium, Inesiosporium, Graphium, Dactylella, Cylindrocarpon, Paecilomyces, Leptosphaeria, Leptographium, Chaetomium, Cercospora, Spadicoides, Pithomyces, Sphacelotheca, and Pyricularia.

Even when found at low incidence in the seeds, some fungi may represent a risk to pastures, for example, Ustilago sp. is potentially pathogenic to forage grasses and causes smut, a disease that affects seed production (Marchi et al., 2009). Cases of this disease have been reported in more than $50 \%$ seed batches from production fields in Mato Grosso do Sul, and its control is not defined in the literature (Marchi et al., 2009). In the present study, Ustilago sp. was found in only seeds from Paraíso das Águas, MS.

Nine genera of fungi were considered to have medium incidence, as they were detected in $0.6-4 \%$ of the seeds. These were Tilletia, Nigrospora, Claviceps, Helicosporium, Aspergillus, Cladosporium, Penicillium, Rhizopus, and Phoma. Seven genera were verified as high incidence because they were present in more than $4 \%$ of the seeds. The seven genera were as follows: Drechslera, Colletotrichum, Exserohilum, Alternaria, Bipolaris, Curvularia, and Fusarium.

Of the seed batches of B. brizantha 'BRS Piatã', $100 \%$ were found to be infected with Fusarium spp., Alternaria sp., Exserohilum sp., and Colletotrichum sp.; 90\%, with Curvularia sp.; 80\%, with Bipolaris sp. and Phoma sp.; 70\%, with Penicillium sp. and Cladosporium sp.; 60\%, with Drechslera sp., Helicosporium sp., Nigrospora sp., and Rhizopus sp.; and 50\%, with Claviceps sp., Aspergillus sp., and Tilletia sp. The high incidence of these fungi is worrisome, mainly, Bipolaris sp., Fusarium spp., Alternaria sp., Curvularia sp., Phoma sp., Claviceps sp., and Drechslera sp., as they are potentially pathogenic for tropical forage grasses and transmitted via seeds (Marchi et al., 2010a, b; Mallmann et al., 2013).

Similar values were observed for Tilletia sp. $(1 \pm 1 \%)$, Cladosporium sp. (1 $\pm 1 \%)$, Penicillium sp. $(2 \pm 1 \%)$, Rhizopus sp. (2 $\pm 2 \%)$, Phoma sp. $(3 \pm 2 \%)$, and Colletotrichum sp. (5 \pm $2 \%)$ in all the production fields. Of these, Cladosporium sp., Penicillium sp., and Rhizopus sp. were considered secondary, saprophytic, or storage fungi by Marchi et al. (2010a, b).

Tilletia sp. is a causal agent of smuts in forage grasses and represents a phytosanitary barrier for the export of seeds (Orué, 2014), thus preventing the commercialization of seeds from Santo Anástacio, SP; Palmeira do Goiás, GO; São Desidério, BA; Costa Rica, MS; and Paraíso das Águas, MS. Colletrotrichum sp. was verified in the seeds from all production fields. Phoma sp. was not found in only batches from Dracena, SP, and Unaí, MG. These fungi were considered potentially pathogenic for forage grasses in a study performed by Marchi et al. (2010a, b). The other genotypes of fungi found in the seeds are listed in Table 2, and their incidence ranged from medium to high, with differences between the production fields.

Fusarium spp. showed a high incidence in the B. brizantha 'BRS Piatã' seeds, with values ranging from 13 to $43 \%$. The highest percentages of seeds with this fungus were observed in the batches from São Desidério, BA, and Correntina, BA; Paraíso das Águas, MS; Tupaciguara, MG, and Unaí, MG; and Costa Rica, MS, and.

The high incidence of Fusarium spp. was caused may be by the favorable climatic conditions in the forage seed-producing regions and continued production in areas infested by the fungi because of increased inoculum potential. Such occurrences were observed by Mallmann et al. (2013), when they evaluated fungi associated with Brachiaria sp. and Panicum maximum in the States of Mato Grosso do Sul, Mato Grosso, and Minas Gerais.

The highest percentages of seeds with Curvularia sp. were found in the batches produced in Santo Anastácio, SP; Costa Rica, MS; and Jataí, GO (33, 35, and 16\%, respectively). The seeds from Dracena, SP, were differentiated from the seeds from Santo Anastácio, SP, Correntina, BA, and Costa Rica, MS.

Curvularia sp. can be found lodged in both the integument and endosperm of forage grass seeds; it can reduce germination and be transmitted to the plant, causing leaf spots

Table 2. Percentage of incidence of potentially pathogenic fungi in Brachiaria brizantha 'BRS Piatã' seeds from different production regions

\begin{tabular}{|c|c|c|c|c|c|c|c|c|c|c|}
\hline $\begin{array}{l}\text { Fungi } \\
\text { genera }\end{array}$ & $\begin{array}{c}\text { Santo } \\
\text { Anastácio } \\
\text { - SP }\end{array}$ & $\begin{array}{c}\text { Dracena } \\
\text { - SP }\end{array}$ & $\begin{array}{l}\text { Jatá́ } \\
\text { - G0 }\end{array}$ & $\begin{array}{l}\text { Palmeiras } \\
\text { de Goiás } \\
\text { - GO }\end{array}$ & $\begin{array}{c}\text { São } \\
\text { Desidério } \\
\text { - BA }\end{array}$ & $\begin{array}{c}\text { Correntina } \\
\text { - BA }\end{array}$ & $\begin{array}{c}\text { Tupaciguara } \\
\text { - MG }\end{array}$ & $\begin{array}{l}\text { Unaí } \\
\text { - MG }\end{array}$ & $\begin{array}{l}\text { Costa } \\
\text { Rica } \\
\text { - MS }\end{array}$ & $\begin{array}{c}\text { Paraíso } \\
\text { das Águas } \\
\text { - MS }\end{array}$ \\
\hline & \multicolumn{10}{|c|}{$(\%)$} \\
\hline Fusarium spp. & $14 \mathrm{a}$ & $18 a b$ & $13 \mathrm{a}$ & $22 \mathrm{ab}$ & $43 c$ & $40 \mathrm{bc}$ & $29 a b c$ & $29 a b c$ & $28 \mathrm{abc}$ & 37 bc \\
\hline Curvularia sp. & $33 d$ & $13 \mathrm{bc}$ & $16 \mathrm{~cd}$ & $10 a b c$ & $4 a b c$ & $0 \mathrm{a}$ & $2 a b$ & $1 \mathrm{ab}$ & $35 \mathrm{~d}$ & $9 a b c$ \\
\hline Bipolaris sp. & $3 a b$ & $0 \mathrm{a}$ & $22 \mathrm{~cd}$ & $12 \mathrm{bcd}$ & $5 \mathrm{ab}$ & $5 a b$ & $14 \mathrm{bcd}$ & $0 \mathrm{a}$ & $13 \mathrm{bcd}$ & $29 d$ \\
\hline Alternaria sp. & $2 \mathrm{a}$ & $5 a b$ & $15 \mathrm{bc}$ & $3 a$ & $9 a b$ & $24 \mathrm{c}$ & $1 \mathrm{a}$ & $13 a b c$ & $3 a$ & $5 a b$ \\
\hline Exserohilum sp. & $19 b$ & 18 b & $1 \mathrm{a}$ & $1 \mathrm{a}$ & $1 \mathrm{a}$ & $1 \mathrm{a}$ & $5 a b$ & $6 a b$ & $2 a$ & $6 a b$ \\
\hline Drechslera sp. & $0 \mathrm{a}$ & $0 \mathrm{a}$ & $14 b$ & $12 \mathrm{~b}$ & $1 \mathrm{a}$ & $0 \mathrm{a}$ & $11 \mathrm{~b}$ & $0 \mathrm{a}$ & $2 \mathrm{a}$ & $5 a b$ \\
\hline Claviceps sp. & $2 a b$ & $0 \mathrm{a}$ & $3 a b$ & $5 b$ & $0 \mathrm{a}$ & $0 \mathrm{a}$ & $0 \mathrm{a}$ & $0 \mathrm{a}$ & $1 \mathrm{ab}$ & $2 a b$ \\
\hline Helicosporium sp. & $0 \mathrm{a}$ & $0 \mathrm{a}$ & $2 \mathrm{a}$ & $1 \mathrm{a}$ & $1 \mathrm{a}$ & $0 \mathrm{a}$ & $2 \mathrm{a}$ & $0 \mathrm{a}$ & $1 \mathrm{a}$ & $6 \mathrm{~b}$ \\
\hline Pithomyces sp. & $1 \mathrm{ab}$ & $0 \mathrm{a}$ & $0 \mathrm{a}$ & $0 \mathrm{a}$ & $3 \mathrm{~b}$ & $0 \mathrm{a}$ & $0 \mathrm{a}$ & $0 \mathrm{a}$ & $1 a b$ & $0 \mathrm{a}$ \\
\hline Nigrospora sp. & $0 \mathrm{a}$ & $1 a b$ & $1 \mathrm{ab}$ & $1 a b$ & $5 b$ & $4 a b$ & $0 \mathrm{a}$ & $0 \mathrm{a}$ & $0 \mathrm{a}$ & $1 \mathrm{ab}$ \\
\hline Aspergillus sp. & $0 \mathrm{a}$ & $2 a b$ & $4 \mathrm{~b}$ & $4 \mathrm{~b}$ & $1 a b$ & $1 a b$ & $0 \mathrm{a}$ & $0 \mathrm{a}$ & $0 \mathrm{a}$ & $0 \mathrm{a}$ \\
\hline
\end{tabular}

Means followed by the same letter in the line do not differ from each other according to the Kruskal-Wallis test at 0.05 probability level 
(Santos et al., 2014). For P. maximum 'Mombaça', this fungus was considered as one of the most common phytopathogens in the seed production fields in the states of Mato Grosso and Mato Grosso do Sul (Mallmann et al., 2013).

Seeds with Bipolaris sp. were not found in the batches from Dracena, SP, and Unaí, MG. These did not differ statistically from those from Santo Anastácio, SP, with an incidence of $3 \%$, and from the municipalities of the state of Bahia, with an incidence of $5 \%$.

Bipolaris sp. was identified in the seeds from Paraíso das Águas, MS, with an incidence of $29 \%$; these did not differ from the seeds from the state of Goiás and municipalities Tupaciguara, MG, and Costa Rica, MS, which showed incidences from 12 to $22 \%$. Marchi et al. (2010a, b) and Santos et al. (2014) evaluated the seed batches of forage grasses and concluded that Bipolaris sp. is pathogenic and has a seed-toseedling transmission rate of $100 \%$. This fungus was detected as a cause of leaf spot in pastures of $P$. maximum 'Mombasa' and 'Tanzania' (Mallmann et al., 2013).

A higher incidence of Alternaria sp. (24\%) was observed in the seeds from Correntina, BA, as well as Jataí, GO, and Unaí, MG (15 and 13\%, respectively). Seeds from the other provenances showed equal or less than $9 \%$ Alternaria sp. infection. Marchi et al. (2010a) considered this fungus as a secondary or storage fungus in commercial batches of Brachiaria seeds.

The fungus Exserohilum sp. was detected in all the evaluated batches. However, a high incidence was observed in only the seeds from the municipalities of Santo Anastácio, SP, and Dracena, SP (19 and 18\%, respectively), which did not differ from each other; these values did not differ from those of the seeds from Tupaciguara, MG; Unaí, MG; and Paraíso das Águas, MS (5, 6, and 6\% infection, respectively).

In contrast to the obtained results, Exserohilum sp. has been rarely reported in forage grass seeds. Santos et al. (2014) analyzed 28 seed batches of Brachiaria spp., Panicum sp., Crotalaria sp., and Stylosanthes sp. and found Exserohilum sp. in only seeds of P. maximum 'Mombasa', but at an incidence of less than $1 \%$.

A high incidence of Drechslera sp. was detected in the seeds from Jataí, GO; Palmeiras de Goiás, GO; Tupaciguara, MG; and Paraíso de Águas, MS (14,12, 11 and 5\%, respectively). Drechslera sp. was not found in two batches from the municipalities of the state of São Paulo and the batch from Correntina, BA, and from Unaí, MG. The non occurrence of Drechslera sp. in the seeds produced in these municipalities did not differ from those observed in the seeds of São Desidério, BA, Costa Rica, MS, and Paraíso das Águas, MS (low incidence of 1,2 , and $5 \%$, respectively). Drechslera sp. has been classified as the main pathogen in Brachiaria seeds by a seed analysis laboratory in San Lorenzo, Paraguay (Pazos et al., 2011).

The etiological agent of ergot was first described as Claviceps, a perfect form of Sphacelia sp. (Miedaner \& Geiger, 2015). This fungus was found only in the seeds from Palmeiras de Goiás, GO; Santo Anastácio, SP; Jataí, GO; Costa Rica, MS; and Paraíso das Águas, MS. Claviceps sp. is potentially pathogenic in crops of rye, sorghum, and millet (Miedaner \& Geiger, 2015). Therefore, seeds of B. brizantha 'BRS Piatã' infected by Claviceps sp. can be considered as a source of inoculum for new areas and crops. In addition, the presence of this pathogen in seeds destined for the international market may constitute a barrier to Brazilian export (Marchi et al., 2010a, b).

The highest incidence of Helicosporium sp. was found in the seeds from Paraíso das Águas, MS, with 6\% seeds being contaminated. In the other production fields, this value was equal to or less than $2 \%$. It is worth noting the absence of this fungus in seed batches from two municipalities of the state of São Paulo, Correntina, BA, and Unaí, MG. Fungi of this genus are not considered phytopathogenic; rather, they are saprophytes because they are found in decomposing material (Silva et al., 2014).

Pithomyces sp. was found in 3\% of the seeds from São Desidério, BA, which did not differ from those from Santo Anastácio, SP, and Costa Rica, MS (both, $1 \%$ incidence). In the other seed batches, no occurrence of this fungus was detected. This genus has been reported in the leaves of $B$. brizantha 'BRS Piatã' and Brachiaria decumbens (Sbalcheiro et al., 2014). In B. decumbens, the occurrence of Pithomyces sp. was associated with intoxication of sheep due to grazing in a contaminated pasture in the state of Mato Grosso (Mendonça et al., 2008).

Higher incidences of Nigrospora sp. and Aspergillus sp. were found in the seeds from São Desidério and Correntina, BA, and Jataí and Palmeiras de Goiás, GO, with values equal or lower than $5 \%$. These fungi were considered secondary, saprophytic, or storage fungi by Marchi et al. (2010a, b). The incidence of these fungi can be justified by the 6 months that elapsed between the arrival of the seeds in the laboratory and beginning of the evaluation.

To analyze the principal components of the sanitary quality of B. brizantha 'BRS Piatã' seeds, Fusarium spp., Curvularia sp., Bipolaris sp., Alternaria sp., and Exserohilum sp. were selected for the following reasons: (i) occurred in at least $80 \%$ of the production sites (Table 2); (ii) statistically different incidence values between the production sites; and (iii) compared to other pathogens, they had a high total incidence (more than 4\%).

The fungi Fusarium spp., Curvularia sp., Bipolaris sp., Alternaria sp., and Exserohilum sp. and the main climatic factors of the production sites (maximum, average, and minimum temperature during the maturation and harvesting period and accumulated precipitation during the maturation and harvest periods) comprised a total of 13 variables for evaluation in the principal component analysis (Table 3).

The results of the statistical correlation analysis identified two principal components as necessary for the interpretation of the data on the variability in sanitary seed quality and climatic factors of the production sites of B. brizantha 'BRS Piatã. Principal components 1 and 2 presented a total variance of 33.44 and $31.21 \%$, respectively, and the sum of these values was $64.65 \%$ of the accumulated variance. These values were close to those found by Silva et al. (2017) in a study on vigor tests for the evaluation of the physiological quality of seeds of the same species. Therefore, the values of the principal components met the recommendation of Rencher \& Christensen (2012), who stated that approximately $70 \%$ of the total variance must be explained by the principal components. 
Table 3. Correlation of variables with each principal component and variability of sanitary quality seed and climatic factors data of 10 lots of Brachiaria brizantha 'BRS Piatã'

\begin{tabular}{llcc}
\hline & \multicolumn{1}{c}{ Variables } & \multicolumn{2}{c}{ Principal components } \\
\cline { 2 - 4 } & Fusarium spp. & $\mathbf{1}$ & $\mathbf{2}$ \\
Sanitary & Curvularia sp. & -0.80 & -0.02 \\
quality & 0.55 & 0.33 \\
& Bipolaris sp. & -0.25 & 0.77 \\
& Alternaria sp. & -0.55 & -0.17 \\
& Exserohilum sp. & 0.91 & -0.07 \\
\hline \multirow{4}{*}{ Maximum maturation temperature } & 0.06 & -0.87 \\
& Maximum harvest temperature & -0.71 & -0.57 \\
Climatic & Average maturation temperature & 0.33 & -0.87 \\
factors & Average harvest temperature & -0.62 & -0.87 \\
& Minimum maturation temperature & 0.61 & -0.61 \\
\cline { 2 - 4 } & Minimum harvest temperature & 0.11 & -0.72 \\
& Accumulated rainfall on maturation & 0.02 & -0.05 \\
& Accumulated rainfall on harvest & 0.90 & -0.05 \\
Eigenvalues & 4.35 & 4.05 \\
Total Variance (\%) & 33.44 & 31.21 \\
Accumulated Variance & \multicolumn{2}{c}{64.64} \\
\hline
\end{tabular}

For each principal component, all correlation values equal to or greater than 0.6 were considered relevant and with discriminatory power (Silva et al., 2017). Thus, among the variables, only Curvularia sp., Alternaria sp., and accumulated rainfall during the maturity period were not discriminatory in the two principal components (Table 3 ).

In the correlation analysis of principal component 1 , the incidence of Fusarium spp. and Exserohilum sp. in the seeds from different production sites was verified to be influenced by maximum and average temperature during harvest, minimum temperature during the maturation period, and accumulative rainfall during harvest time. Because of the similar sizes of the vectors, it was possible to infer that the variable incidence of Fusarium spp. and Exserohilum sp., in addition to the accumulative precipitation during the harvest, presented greater discriminatory power and could be considered equally representative in the separation of the batches

For the correlation analysis of principal component 2, the incidence of Bipolaris sp., maximum temperature during the maturation period, average and minimum temperatures during maturation, and harvesting periods presented discriminatory power for the batches, as the values were equal to or greater than 0.6 (Table 3 ). These variables were equally representative in the separation of the batches because of the similar sizes of the vectors, except for minimum temperature during the maturity period (which presented a vector).

Thus, it can be inferred that the fungi Fusarium spp., Bipolaris sp., and Exserohilum sp. must have infected the seeds of B. brizantha 'BRS Piatã' at the end of the maturation period. Seeds of forage grasses are harvested by soil sweeping, after the seeds had fallen from the plant, and are exposed to environmental conditions and contamination of saprophytic fungi (Quadros et al., 2012). The inocula of Fusarium spp., Bipolaris sp., and Exserohilum sp. may occur in saprophytic forms, such as resistance structures in the soil; secondary hosts; or in seeds, on the integument and/or in the interior (Quadros et al., 2012; Santos et al., 2014; Amorim et al., 2016).

For principal component 1 , the incidence variables of Fusarium spp., maximum and average temperature during harvest, were inversely proportional to those of Exserohilum sp., minimum temperature during the maturation period and accumulated precipitation during the harvest period; this can be verified by negative and positive values, respectively (Table 3).

Therefore, it can be inferred that the incidence of Fusarium spp. in the seeds was higher at higher temperatures, between 30.3 and $32.0{ }^{\circ} \mathrm{C}$ maximum temperatures and between 22.2 and $24.2^{\circ} \mathrm{C}$ minimum temperatures, and lower accumulated rainfall during harvest, less than $82 \mathrm{~mm}$ (Table 1, Figure 1).

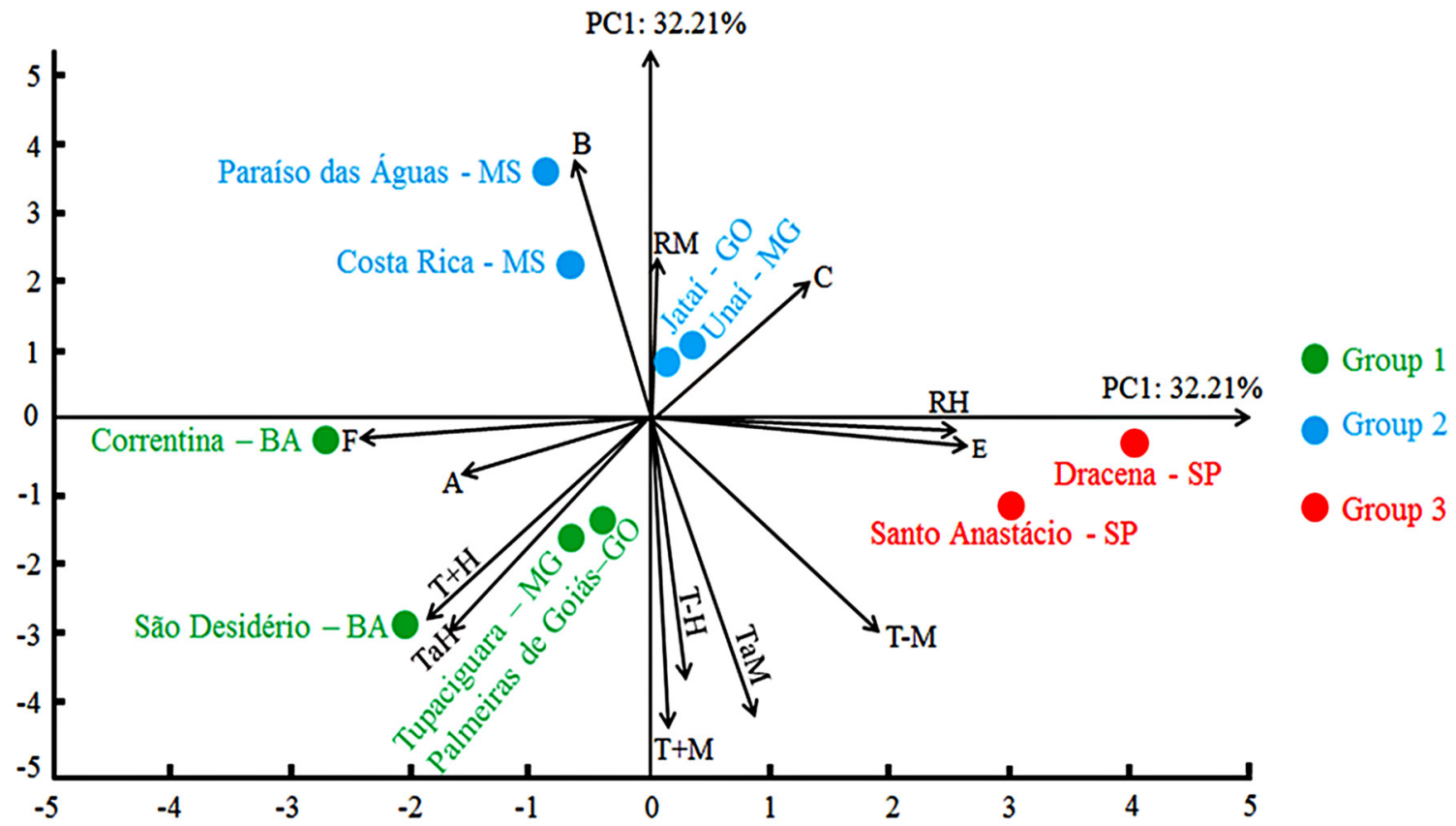

Figure 1. Biplot-type dispersion scheme with circle of eigenvectors obtained by the analysis of two principal components (PC1 and PC2) established based on variables of Fusarium spp. (F), Curvularia sp. (C), Bipolaris sp. (B), Alternaria sp. (A), Exserohilum sp. $(\mathrm{E})$, maximum $(\mathrm{T}+)$, minimum $(\mathrm{T}-)$ and average $(\mathrm{Ta})$ temperature and accumulated rainfall $(\mathrm{R})$ on maturation $(\mathrm{M})$ and harvest $(\mathrm{H})$ in the evaluation of the sanitary quality of 10 of Brachiaria brizantha 'BRS Piatã' seeds from different production regions 
The municipalities of Palmeiras de Goiás, GO; São Desidério, BA; Correntina, BA; and Tupaciguara, MG constituted group 1 , which presented most of these characteristics.

Conditions of high temperatures and low relative humidity have been reported to be unfavorable to the development of fungi (Souza, 2001; Amorim et al., 2016) such as Fusarium spp. However, during the harvest period, Brachiaria seeds remain under a layer of straw, which acts as a thermal insulator and results in the formation of a microclimate where the temperature is cooler and relative humidity is higher (Silva Júnior et al., 2016). Therefore, during the harvest period, conditions in which the seeds of $B$. brizantha 'BRS Piatâ' remain under straw may be favorable for fungal growth. Furthermore, the incidence of this fungus may be related to the presence of the inoculum in the area or B. brizantha 'BRS Piatã' seeds (Santos et al., 2014).

The seeds from Santo Anastácio, SP, and Dracena, SP, constituted group 3 . The seeds from these municipalities showed a higher incidence of Exserohilum sp., which was consistent with lower temperatures of 20.1 and $20.2{ }^{\circ} \mathrm{C}$ (minimum) and high accumulated precipitation during harvest, 167 and $181 \mathrm{~mm}$. These harvest conditions activate metabolism and process of seed deterioration (Carvalho \& Nakagawa, 2012) and are favorable to pathogens (Amorim et al., 2016).

In principal component 2 , the incidence variables of Bipolaris sp. were inversely proportional to the temperature variables. This was checked by positive and negative values, respectively; therefore, group 2 was formed by the seeds produced in Jataí, GO; Costa Rica, MS; and Paraíso das Águas, MS. The seeds from Paraíso das Águas, MS, and Costa Rica, MS, were more affected by the incidence of Bipolaris sp. than the seeds from the other regions. This was verified in the dispersion plane by the proximity between these sites and eigenvector of the pathogen.

The incidence of Bipolaris sp. may be related to the lower temperatures recorded at these locations, between 19.2 and $20.0^{\circ} \mathrm{C}$, during the maturation of the seeds (Table 1), mainly after the seed had fallen from the plant and was in contact with the soil. This can be verified by the position of the eigenvectors in the opposite quadrant of the dispersion plane.

The increase in the incidence of Bipolaris sp. is favored by temperatures between 22 and $30^{\circ} \mathrm{C}$ (Amorim et al., 2016). Possibly, this fact and the presence of the inoculum in the soil of some production sites, such as Mato Grosso do Sul, favored the incidence of this fungus.

\section{Conclusions}

1. Production sites where the maximum temperatures are above $30{ }^{\circ} \mathrm{C}$, average temperature close to $25^{\circ} \mathrm{C}$, and rainfall accumulation below $82 \mathrm{~mm}$ during harvest time were favorable for Fusarium spp. in the seeds of B. brizantha 'BRS Piatã.

2. The incidence of Bipolaris sp. in the seeds of B. brizantha 'BRS Piatã' is higher in places with temperatures between 19 and $20^{\circ} \mathrm{C}$ during maturation.

3. The highest incidence of Exserohilum sp. was observed at sites where the temperature at harvest is close to $20^{\circ} \mathrm{C}$ and accumulated rainfall is between 167 and $181 \mathrm{~mm}$.

\section{Literature Cited}

Amorim, L.; Rezende, J. A. M.; Bergamin Filho, A.; Camargo, L. E. A. Manual de fitopatologia: Doenças das plantas cultivadas. São Paulo: Agronômica Ceres, 2016. 573p.

Araújo, S. A. C.; Deminicis, B. B.; Campos, P. R. S. S. Melhoramento genético de plantas forrageiras tropicais no Brasil. Revista Archivos de Zootecnia, v.57, p.61-76, 2008.

Brasil. Ministério da Agricultura, Pecuária e do Abastecimento. Instrução Normativa no 30, de 21 de maio de 2008. Brasília: Diário Oficial da União, 2008. 45p. Seção 1

Brasil. Ministério da Agricultura, Pecuária e do Abastecimento. Regras para análise de sementes. Brasília: MAPA, 2009. 395p.

Carvalho, N. M.; Nakagawa, J. Sementes: Ciência, tecnologia e produção. Jaboticabal: FUNEP, 2012. 590p.

Hongyu, K.; Sandanielo, V. L. M.; Oliveira Junior, G. J. de. Análise de componentes principais: Resumo teórico, aplicação e interpretação. Engineering and Science, v.15, p.83-90, 2015.

INMET - Instituto Nacional de Meteorologia. Dados meteorológicos. Disponível em: <http://www.inmet.gov.br/projetos/rede/pesquisa/ inicio.php >. Acesso em: Jan. 2018.

Mallmann, G.; Verzignassi, J. R.; Fernandes, C. D.; Santos, J. M. dos; Vechiato, M. H.; Inácio, C. A.; Batista, M. V.; Queiroz, C. de A. Fungos e nematoides associados a sementes de forrageiras tropicais. Summa Phytopathologica, v.39, p.201-203, 2013. https://doi.org/10.1590/S0100-54052013000300010

Marchi, C. E.; Fernandes, C. D.; Bueno, M. L.; Batista, M. V.; Fabris, L. R. Fungos veiculados por sementes comerciais de braquiária. Arquivos do Instituto Biológico, v.77, p.65-73, 2010a.

Marchi, C. E.; Fernandes, C. D.; Bueno, M. L.; Batista, M. V.; Fabris, L. R. Microflora fúngica de sementes comerciais de Panicum maximum e Stylosanthes spp. Semina: Ciências Agrárias, v.31, p.575-584, 2010b. https://doi.org/10.5433/1679-0359.2010v31n3p575

Marchi, C. E.; Fernandes, C. D.; Machado, J. da C.; Vechiato, M. H.; Fabris, L. R.; Batista, M. V.; Sorgatto, M.; Salles, N. E. P. C.; Barbosa, C. da S. Incidência de Ustilago operta em sementes comerciais de braquiária. Arquivo Instituto de Biologia, v.76, p.121-125, 2009.

Martins, C. C.; Melo, P. A. F. R. de; Pereira, F. E. C. B.; Anjos Neto, A. P. dos; Nascimento, L. C. do. Sanitary quality of Brachiaria brizantha cv. Marandú and Xaraés seeds harvested in different states in Brazil. Bioscience Journal, v.33, p.1431-1440, 2017. https://doi.org/10.14393/BJ-v33n6a2017-36533

Melo, L. F.; Silva, G. Z. da; Panizzi, R. C.; Martins, C. C. Processing on the sanitary quality of seeds of Panicum maximum cv. 'Tanzânia.' Revista Brasileira de Engenharia Agrícola e Ambiental, v.21, p.715-720, 2017. https://doi.org/10.1590/1807-1929/agriambi.v21n10p715-720

Mendonça, F. de S.; Camargo, L. M. de; Freitas, S. H. de; Dória, R. G. S.; Baratella-Evêncio, L.; Evêncio Neto, J. Aspectos clínicos e patológicos de um surto de fotossensibilização hepatógena em ovinos pela ingestão de Brachiaria decumbens (Gramineae) no município de Cuiabá, Mato Grosso. Ciência Animal Brasileira, v.9, p.1034-1041, 2008.

Miedaner, T.; Geiger, H. H. Biology, genetics, and management of ergot (Claviceps spp.) in rye, sorghum, and pearl millet. Toxins, v.7, p.659-678, 2015. https://doi.org/10.3390/toxins7030659

Orué, H. J. S. Reporte de la micobiota uredinal y ustilaginal en poáceas forrajeras en Paraguay. Investigación Agraria, v.16, p.124-128, 2014. 
Pazos, T.; Sarubbi, H.; Aquino, A. Evaluación de hongos fitopatógenos en semillas de especies forrajeras tropicales. Investigación Agraria, v.13, p.41-47, 2011.

Quadros, D. G. de; Andrade, A. P.; Oliveira, G. C. de; Oliveira, E. P.; Moscon, E. S. Componentes da produção e qualidade de sementes dos cultivares Marandú e Xaraés de Brachiaria brizantha (Hochst. ex A. Rich.) Stapf colhidas por varredura manual ou mecanizada. Semina Ciências Agrárias, v.33, p.20192028, 2012. https://doi.org/10.5433/1679-0359.2012v33n5p2019

Rencher, A. C.; Christensen, W. F. Methods of multivariate analysis. 3.ed. New York: John Wiley Professio, 2012. 758p. https://doi. org/10.1002/9781118391686

Santos, G. R. dos; Tschoeke, P. H.; Silva, L. de G.; Silveira, M. C. A. C. da; Reis, H. B.; Brito, D. R.; Carlos, D. de S. Sanitary analysis, transmission and pathogenicity of fungi associated with forage plant seeds in tropical regions of Brazil. Journal of Seed Science, v.36, p.54-62, 2014. https://doi.org/10.1590/S2317-15372014000100007

Sbalcheiro, C. C.; José, S. C. B. R.; Barbosa, J. C. R. da C. M. Physiological and sanitary quality, and transmission of fungi associated with Brachiaria brizantha (Hochst. ex. A. Rich.) Stapf seeds submitted to thermal and chemical treatments. Journal of Seed Science, v.36, p.443-450, 2014. https://doi. org/10.1590/2317-1545v36n41032
Seifert, K.; Morgan-Jones, G.; Gams, W.; Kendrick, B. The genera of hyphomycetes. Utrecht: CBS-KNAW Fungal Biodiversity Centre, 2011. 866p.

Silva, F. de A. S. e; Azevedo, C. A. V. de. The Assistat software version 7.7 and its use in the analysis of experimental data. African Journal of Agricultural Research, v.11, p.3733-3740, 2016. https://doi.org/10.5897/AJAR2016.11522

Silva, G. Z. da; Martins, C. C.; Cruz, J. de O.; Jeromini, T. S.; Bruno, R. de L. A. Evaluation the physiological quality of Brachiaria brizantha cv. BRS 'Piatã' seeds. Bioscience Journal, v.33, p.572580, 2017. https://doi.org/10.14393/BJ-v33n3-36519

Silva Júnior, A. C. da; Martins, C. C.; Martins, D. Effects of sugarcane straw on grass weeds emergence under field conditions. Bioscience Journal, v.32, p.863-872, 2016. https:// doi.org/10.14393/BJ-v32n4a2016-32782

Silva, S. S. da; Izabel, T. dos S. S.; Gusmão, L. F. P. Fungos conidiais associados a substratos vegetais submersos em algumas áreas do bioma Caatinga. Rodriguésia, v.65, p.527-538, 2014. https://doi. org/10.1590/S2175-78602014000200014

Souza, F. H. D. de. Produção de sementes de gramíneas forrageiras tropicais. São Carlos: Embrapa Pecuária Sudeste, 2001. 43p. Documento, 30 